\title{
THE DISSOLUTION OF THE DIOCESE OF CARANSEBES AND THE FATE OF BISHOP VENIAMIN NISTOR UNDER THE COMMUNIST REGIME
}

\author{
Daniel ALIC*
}

\begin{abstract}
The old Diocese of Caransebes, institution that gathered around the Romanian society from Banat, had an unfortunate destiny. Following the political changes from Romania, occurring since 1948, the role and importance of Romanian Orthodoxy were considerably diminished by the communist regime. Due to the political enmities regarding the Church, the Diocese of Caransebes ended by fusion - on February 5, 1949 - with the Archbishopric of Timisoara. A year before this event occurred, the Theological Academy from Caransebes had to close its gates due to the same political reasons. Veniamin Nistor, ordained as bishop of Caransebes on August 24, 1941, in times of war and in a difficult period for the entire Romanian society, witnessed these dramatic changes in the life of the Church from Banat. Although he proved to be in many ways a true founder and organizer of the diocese through his spiritual, cultural and social vision, Bishop Veniamin Nistor was forced to leave his mission and withdraw from his diocese, as inmate, at Alba Iulia, where he served as an abbot of the Holy Trinity monastery (the Reunification Cathedral). The spiritual sufferings and the health problems caused by his forced departure from Caransebes hastened his death. On February 5, 1963, Bishop Veniamin Nistor passed away and was buried near hermitage St. John the Baptist - Alba Iulia, alongside two other bishops persecuted under the communist regime: Ioan Stroia, bishop of the Army, and Policarp Morusca, the first bishop of all the Romanians from the USA. In the memory of the Diocese of Caransebes, bishop Veniamin Nistor has remained as a true model of devotion and dedication, and for the sufferings he endured due
\end{abstract}

* PhD, Rev. Lecturer, "Eftimie Murgu” University Resita (Faculty of Social Science, Department of Theology), Resita, Romania. 
to the dissolution of the bishopric in 1949, he is celebrated as a martyr of the Church of Banat.

Keywords: Diocese of Caransebes, Bishop Veniamin Nistor, abolishment, communist persecution

\section{Introduction}

Following the endeavours of the leaders of the Romanians in Transylvania and Banat, on December 24, 1864 the Romanian Orthodox Metropolitanate was established with headquarters in Sibiu, Bishop Andrei Saguna from Sibiu becoming the metropolitan (bishop between 1848 and 1864, and metropolitan between 1864 and 1873) ${ }^{1}$. Moreover, Holy Hierarch Andrei Saguna was the leader who led the religious emancipation of the Romanians from the Habsburg Empire for almost 30 years, being the creator of the main ecclesiastic institutions of the Romanians ${ }^{2}$.

The imperial diploma signed by Emperor Franz Joseph on December 24, 1864 also specifies its two dioceses: the Diocese of Arad and the Diocese of Caransebes, although Holy Metropolitan Andrei Saguna wanted the Metropolitan to have more bishops ${ }^{3}$.

Shortly after the Metropolitan of Sibiu was founded the Diocese

${ }^{1}$ Nicolae PoPEA, Vechia Mitropolie ortodoxă română a Transilvaniei, suprimarea şi restaurarea ei [The old Romanian Orthodox Metropolitan of Transylvania, its assassination and restoration], Sibiu, 1870, p. 236-278. For his church organization and efforts to establish a church and cultural life for the Romanians from Transylvania and Banat, in 2011, Metropolitan Andrei Saguna was canonized by the Holy Synod of the Romanian Orthodox Church, with the date of celebration on November $30^{\text {th }}$.

${ }^{2}$ Lucian Mic (Bishop of Caransebeş), Relaţiile Bisericii Ortodoxe Române din Banat cu Biserica Ortodoxă Sârbă în a doua jumătate a secolului al XIX-lea [The relationships of the Romanian Orthodox Church of Banat with the Serbian Orthodox Church in the second half of the nineteenth century], Cluj Napoca / Caransebes, Cluj University Press / the Diocese of Caransebes Publishing House, 2013, p. 145-166.

3 I. D. Suciu, Radu Constantinescu, Documente privitoare la istoria Mitropoliei Banatului [Documents regarding the history of Banat Metropolitanate], Volume II, Timisoara, Metropolitanate of Banat Publishing House, 1980, p. 858; Ioan LuPAŞ, Istoria bisericească a românilor ardeleni [Ecclesiastical History of the Romanians from Transylvania], Cluj-Napoca, Dacia Publishing House, 1995, p. 190. 
of Caransebes was also reactivated. On July 6, 1865, by another imperial diploma, the Diocese of Caransebes resumed its activity ${ }^{4}$ The reason why Metropolitan Andrei Şaguna, after the synod of Karlowitz (1864-1865), wanted to reactivate the Diocesan Centre in Caransebes was precisely the old age of the episcopal chair, which is mentioned in the imperial diploma itself ${ }^{5}$. The Romanian leaders of Banat, among which Andrei Mocioni, wanted the headquarters of the diocese to be in Timisoara. They had a controversy with Andrei Saguna regarding this, but "the will of history had it that the town of Caransebes would be strengthened again with this dignity"'.

The Diocese of Caransebes, immediately after reestablishment, polarized around it the whole Romanian society from Banat. The first bishop of Caransebes was Ioan Popasu, archpriest of Brasov and close collaborator of Saguna ${ }^{7}$. The period of Bishop Popasu, although marked by difficulties inherent to beginnings, was very rich in achievements on a liturgical, academic and cultural level. Thanks to the missionary zeal of the bishop, institutions were created and activated, which meant a strong socio-political and cultural-national momentum for the

${ }^{4}$ It is certainly known that in the early eighteenth century, Bishop Spiridon Stibita chose Caransebes as the city of residence. Not long after that, in 1775, Bishop Vinchentie Popovici moved the bishop's residence in the town of Vrsac, placing it in a systematic contact with the Serbian hierarchy. Additional information at Gheorghe Cotoşman, "Episcopia Caransebeşului până în pragul secolului al XIX-lea" ["The Diocese of Caransebes until the beginning of the nineteenth century"], in Anuarul Academiei Teologice din Caransebeş 1940-1941 [Caransebes Theological Academy Yearbook 1940-1941], Caransebes, The printing press of the diocesan publishing house, 1941, p. 94 and at Andrei GHIDIU, Iosif BALAN, Monografia Caransebeşului [Monograph of Caransebes], $2^{\text {nd }}$ edition, Timisoara, 2000, p. 105-106.

5 The text of the diploma stipulated: "And Caransebes, which in ancient times was a diocese of the Greek Oriental rite, henceforth decide to adorn with the bishop seat and honour..." - cited by I. D. Suciu, R. Constantinescu, Documents regarding..., volume I, p. 68.

${ }^{6}$ Viorel Dorel CHERCIU, “Cadrul istorico-juridic la reînființarea Diecezei Caransebeşului în anul 1865" ["Historical and legal framework at the reestablishment of the Diocese of Caransebes in 1865"], in Societate şi civilizaţie în Banatul istoric [Society and civilization in historical Banat], Timisoara, Mirton Publishing House, 2003, p. 241.

7 Bishop Lucian Mic, "Episcopul Ioan Popasu" ["Bishop Ioan Popasu"], in Mărturisire şi devenire în Episcopia Caransebeşului [Confession and becoming in the Diocese of Caransebes], Timişoara, Mirton Publishing House, 2010, p. 27-31. 
Romanians ${ }^{8}$.

\section{The Diocese of Caransebes and Bishop Veniamin}

The development of the Diocese of Caransebes continued under the following bishops: Nicolae Popea ${ }^{9}$ (1889-1908), Elie Miron Cristea $^{10}$ (1910-1919), who later became the primate metropolitan and patriarch of Greater Romania, Iosif Badescu ${ }^{11}$ (1920-1933), Vasile Lazarescu $^{12}$ (1934-1941), who became bishop of Timisoara, then metropolitan of Banat (in 1947) and Veniamin Nistor (1941-1949) ${ }^{13}$. When Bishop Veniamin came to the episcopal chair of Caransebes, the diocese was one of the most important dioceses of the Romanian Patriarchate, with a beautiful history and a movable and immovable heritage of great value ${ }^{14}$. There was also a Theological Academy with

${ }^{8}$ Constantin BRĂTESCU, Episcopul Ioan Popasu şi cultura bănăţeană [Bishop Ioan Popasu and Banat culture], Timisoara, Metropolitan of Banat Publishing House, 1995, p. 27.

9 I. LuPAŞ, Episcopul Nicolae Popea [Bishop Nicolae Popea], Sibiu, Romanian Orthodox Diocese Printing House, 1933.

10 Mircea PăCURARIU, Dicţionarul teologilor români [Dictionary of the Romanian Theologians], third edition revised and enlarged, Sibiu, Andreiana Publishing House, 2014, p. 190. About the time of pastorate in Caransebes, see Daniel ALIC, Eparhia Caransebeşului în perioada păstoririi episcopului Miron Cristea (1910-1919). Biserică şi societate [The Diocese of Caransebes during the pastorate of bishop Miron Cristea (1910-1919). Church and Society], Cluj-Napoca / Caransebes, Cluj University Press / the Diocese of Caransebes Publishing House, 2013, p. 450.

${ }^{11}$ Constantin CILIBIA, Biserica și societatea bănățeană in timpul păstoririi episcopului dr. Iosif Traian Badescu (1920-1933) [The Church and society in Banat during the pastorate of Bishop dr. Iosif Traian Badescu (1920-1933)], Caransebes, the Diocese of Caransebes Publishing House, 2013.

12 Pavel MARCU, "Episcopul Vasile Lăzărescu" ["Bishop Vasile Lăzărescu"], in Calendarul Românului pe anul 2007 [The Romanian Calendar for 2007], Caransebes, the Diocese of Caransebes Publishing House, 2008, p. 225-226.

13 Daniel Alic, "Episcopul Veniamin Nistor, un mare păstor de suflete din Eparhia Caransebeşului" ["Bishop Veniamin Nistor, a great shepherd of souls in the Diocese of Caransebes"], in Foaia Diecezană [Diocesan Paper], new series, vol. XXI (2015), no. 2 (February), p. 7.

${ }^{14}$ Actele Adunării eparhiale a eparhiei ort. rom. a Caransebeşului pe anul 1940 [The Documents of the Diocesan Assembly of the Romanian Orthodox Diocese of Caransebes for 1940], Caransebes, 1941, p. 84. 
prestigious professors ${ }^{15}$ and articulate monastic life ${ }^{16}$.

All these achievements, to which by generations and generations of believers have contributed, were marginalized by the communist regime immediately after it had access to the Romanian government. The date of August 23, 1944 meant for the Church the beginning of a long series of shortcomings. On March 6, 1945 a Communist government was established to lead Romania which, backed massively by Soviet Russia, fought to remove the historical state forms where the Romanian territory had evolved politically. The complete victory of communism took place on December 30, 1947 when King Michael I of Romania was forced to abdicate, the People's Republic of Romania being proclaimed. Regarding the Church, immediately after the removal of the king, during 1948, many decisions were taken against the church activity, in order to reduce its role in society. In these circumstances, Bishop Veniamin Nistor of Caransebes witnessed the decline of the diocese that he was leading, the abolition of the main institutions of the Church, and ultimately the abolition of the Diocese of Caransebes as an episcopal chair.

The end of the diocese was not sudden and unexpected, but methodical and gradual. Being a man with a long-lasting activity in church administration, Bishop Veniamin had the ability to recognize the methods used by the Communists and fought to save the diocese, but failed to oppose the atheist regime that wanted obstinately to eliminate or at least minimize church life.

For Bishop Veniamin, who proved in many respects to be a true founder, restorer and organizer of the Banat Diocese, the end of the Diocese of Caransebes was a long toil that he could hardly endure. Ordained as the hierarch of the historic Diocese of Caransebes on August 24, $1941^{17}$, difficult times for the entire Romanian society at war, Bishop Veniamin Nistor had a spiritual program and a cultural-

15 Anuarul Academiei Teologice ort. rom. din Caransebes 1940/1941 [Yearbook of the Romanian Orthodox Theological Academy of Caransebes 1940/1941], Caransebes, 1941.

16 Nicolae CoRnEAn, Monografia eparhiei Caransebeş [Monograph of the Diocese of Caransebes], Caransebes, 1940, p. 102-109.

17 See more in Foaia Diecezană [The Diocese Paper], 1941, no. 35 (August 31), p. 111. 
social vision that came to fruition beautifully during his pastorate. In Caransebes, his whole mission was guided by the spirit of brotherhood and mutual understanding because he always tried to create a close spiritual connection between the bishop and the priests, based on love and trust $^{18}$. This made him loved by priests and believers alike, remaining as a model of goodness and wisdom in the tradition of the place $^{19}$. All these spiritual links and the numerous foundations made by Bishop Veniamin ${ }^{20}$ made the pain even more unbearable when the diocese was abolished.

Bishop Veniamin was faced with the shortcomings of the Church and society caused by the communist regime even since the first year of pastoring in Caransebes. Even if within the borders of Romania Communism had no power then, the Romanian brothers from Bessarabia were already entangled in Bolshevism. For their spiritual relief, only one week after his ordaining in Caransebes, Bishop Veniamin together with ten priests of the diocese, participated in the great mission organized by Metropolitan Nicolae of Transylvania among the Romanians from Bessarabia and Transnistria ${ }^{21}$.

On returning home, Bishop Veniamin sent a circular letter to the priests and believers of the diocese, in which he said:

"I could not come earlier with Our bishop's word in your midst because a few days after I was ordained as a bishop I had to go together with 10 priests of our diocese and with all the bishops of Transylvania, led by His Eminence our Metropolitan Nicolae, and with other 43 priests, on a Christian and Romanian mission to our brothers from Bessarabia and Transnistria, released not long ago from the Bolshevik

${ }^{18}$ Foaia Diecezană [The Diocese Paper], 1941, no. 35 (August 31), p. 1-3.

${ }^{19}$ Oral tradition records that if a priest had to be rebuked for negligence in the priestly ministry, at the end of the discussion he would embrace him and tell him to cheer up because no priest can leave feeling upset from his bishop.

20 Daniel ALIC, "Activitatea pastoral-culturală şi de asistenţă socială a episcopului Veniamin Nistor al Caransebeşului (1941-1949)" ["The pastoral-cultural and social assistance activity of Bishop Veniamin Nistor of Caransebes (1941-1949)"], in Fr. Daniel Alic (coord.), Taină şi mărturisire [Sacrament and confession], Caransebes, Diocese of Caransebes Publishing House, 2011, p. 347-356.

21 Actele Adunării eparhiale a Eparhiei ortodoxe române a Caransebeşului [The Documents of the Diocesan Assembly of the Romanian Orthodox Diocese of Caransebes], Caransebes, 1942, p. 54. 
hell through the bravery of the Romanian soldier ...

We went on those lands on behalf of the Gospel of our Lord and Saviour Jesus Christ, on behalf of Transylvania, which knows what suffering under a 1000-year rule means, so as to bring to our brothers the comforting word of love and faith after the suffering they had to endure; to wipe the tears that wet their cheeks, to strengthen their faith in God and to pray together to our heavenly Father to chase away the enemy and to thank Him because He intended for them to see the day of their salvation from the oppression and tyranny of the godless. And this victory came when anger was greater because God is closer, with His grace and help, to those who put their whole faith and hope in Him when danger is terrible" $" 22$.

\section{The end of the Diocese}

Although Romania was oriented towards the socialist politics since 1944, the pressure on the religious centres began to be evident later, 1948 being decisive for the destiny of many diocesan centres, theology schools and other institutions of the Church. Before starting organized persecution, the bishops, deans, priests and the auxiliary church staff were forced to sign documents of loyalty to the state, being considered the first opponents of the new communist political power. Bishop Veniamin Nistor signed on January 2, 1948, before the Chairperson of the Court of Caransebes, Dr. Liviu Plavosin, assisted by court clerk Ilie Munteanu, a loyalty oath: "I swear to be faithful to the people and to defend the People's Republic of Romania against enemies from without and within. I swear to comply with the laws of the People's Republic of Romania and to keep secrecy in service"23. It was a gesture of humility since the Bishop was known to be Anti-Soviet, his previous actions proving it. After the clergy swore allegiance to the People's Republic of Romania, several ministerial acts were issued in order to discredit the priests and to reduce the influence and credibility of the Church among people.

On January 23, 1948, the Diocese of Caransebes received a document stating that "following the historic act of December 30, 1947"

22 Archive of the Diocese of Caransebes (hereinafter ADC), Church Fund III, File 95/1941, reg. no. 184 / 1941.

${ }^{23}$ Ibidem, File 9/1948, unnumbered. 
the monarchy was abolished and the People's Republic of Romania was established. Then it was asked that all publications bearing the image of the former king or any member of the former royal family should be removed immediately from circulation "in order not to cause folly in the hearts of the believers, thus contributing concretely to the understanding of the new spirit of popular democracy" 24 .

The same directives were sent to the Romanian Patriarchate, Permanent Synod of the Romanian Orthodox Church, at the meeting of January 8th, 1948, when it was decided to change the formulas of remembering the country's leaders, the "High Chair of the People's Republic of Romania" will be mentioned instead of the king ${ }^{25}$. The same act specifies that the former Kings Carol I and Ferdinand I and Queens Elisabeth and Mary can only be mentioned in the churches they founded ${ }^{26}$.

On February 24, 1948, the Diocese of Caransebes was informed that instead of the paintings with the kings of Romania, the Ministry of Information edited other paintings, images with the following being exposed prominently on the walls: Ana Pauker, Gheorghe Gheorghiu Dej, Vasile Luca, Dr. Petru Groza, Emil Bodnaras, Vladimir Ilici Lenin, Teohari Georgescu ${ }^{27}$. According to these orders, the Archdiocesan Council asked the parishes to buy the new country emblem, the map of the People's Republic of Romania, and the painting of the members of the High Chair ${ }^{28}$.

From documents and political and church events it can be seen that the decision to abolish the Diocese of Caransebes was made during 1948 , but the actual abolition of the historic diocese was done slowly by phasing out its institutions and by taking over its immovable property for social reasons. Being in the border area and having a revolutionary past, Banat was strictly supervised. The Ministry of Culture, designed to control the activity of the Church, sent a document to the Diocese of Caransebes on March 23, 1948 requesting that the Diocesan Centre

\footnotetext{
${ }^{24}$ Ibidem, File 32/1948, unnumbered.

${ }^{25}$ Ibidem, File 12/1948, unnumbered.

${ }^{26}$ Ibidem.

${ }^{27}$ ADC, Trustee Fund V, File 88/1948, unnumbered.

${ }^{28}$ Ibidem.
} 
"should exert strict supervision of how the priests fulfil their mission and as citizens of the People's Republic of Romania"29. The most supervised priests were those with an important church activity and results in guiding the believers ${ }^{30}$.

From the second half of 1948 certain state institutions began to take possession of the Church buildings: the Theological Academy ${ }^{31}$, the academy boarding house, the headquarters of the religious associations and even the diocese headquarters were demanded ${ }^{32}$. All these actions as well as the rumours that the abolition of the diocese is imminent were showing the end of the historical episcopal chair from Caransebes. With these rumours it was tried to compromise Bishop Veniamin. After Decree no. 358 of December 1, 1948, when the United Diocese of Lugoj was disbanded and many priests were imprisoned, the communist authorities moved the diocese of Caransebes to Lugoj, in the headquarters of the United Diocese. It was just a diversion, because Bishop Veniamin Nistor was afterwards accused of wanting to abolish the Diocese of Lugoj. Thus, it was tried to discredit the bishop, but also to put an ecclesiastical robe on the political decision ${ }^{33}$.

At the end of 1948 the buildings owned by the Diocesan Centre of Caransebes had largely been requisitioned and there was already a Clinic in operation there, a school for young children, the Forestry School, the Red Cross and the offices of the Romanian Railways ${ }^{34}$.

At the beginning of 1949 the expected occurred. Through presidium decree no. 134 of 1949 published in the Official Gazette no.

${ }^{29}$ ADC, Church Fund III, File 118/1948, unnumbered.

${ }^{30}$ Ibidem.

31 Vasile PETRICA, Academia Teologică Ortodoxă Română Caransebeş (1927-1948) [The Romanian Orthodox Theological Academy of Caransebes (1927-1948)], Timisoara, David Press Print, 2014, p. 231-233.

32 ADC, Economic Fund V, File 299/1948, unnumbered. Caransebes Social Insurance House asked the Ministry of Internal Affairs in November 1948 to be moved to the headquarters of the Romanian Workers' Party, the offices of the Archdiocesan Council being confiscated for the latter's headquarters.

33 Details at Vasile PETRICA, "Episcopul Veniamin Nistor în văpaia anului 1948" ["Bishop Veniamin Nistor in the flame of 1948"], in Daniel Alic (coord.), Taină şi mărturisire [Sacrament and confession], Caransebes, Diocese of Caransebes Publishing House, 2011, p. 356-362.

${ }^{34}$ ADC, Economic Fund V, File 343/1948, unnumbered. 
30 of February 5, 1949, the Diocese of Caransebes did not emerge as a separate ecclesiastical institution. The new canonical-administrative organization of the Romanian Orthodox Church showed that the Diocese of Caransebes was abolished by merging with the Archdiocese of Timisoara, thus forming the Archdiocese of Timisoara and Caransebes" ${ }^{35}$. Of all the institutions created in the Diocese of Caransebes since 1865 until abolition only the Archpriestship and School of Church Singers remained.

Metropolitan Vasile Lazarescu from Timisoara, accused at the time that he wanted the abolition of the Diocese of Caransebes since the time of his pastorate in Caransebes ${ }^{36}$, sent a document to Caransebes on February 19, 1949, announcing:

"manner of handing and taking over the inventory of the Diocese of Caransebes: We rule that handing and taking over the inventory of the Diocese of Caransebes by the Diocesan Council to the Archdiocesan Council will take place on February 21, 1949, and in the coming days until completion.

The delegates from the Archdiocesan Council for the takeover are: High Reverend Priest Vicar Ioan Craciunel, Reverend Priest Dr. Traian Coseriu, reviewer advisor, and Mr. Nicolae Cornean, reviewer advisor, and Priest Stefan Teretean, accountant, will take part in the official takeover as a specialist. The Venerable Diocesan Council of Caransebes will appoint its delegates." 37

\section{Bishop Veniamins's faith}

Bishop Veniamin Nistor, left alone in front of persecution, had to comply with the decision to leave, with forced residence in Alba Iulia. The contemporaries to the event record in their memoirs that at the end of February, Bishop Veniamin Nistor went to Alba Iulia by train,

${ }^{35}$ Foaia Diecezană [The Diocese Paper], 1949, no. 1/24 April, p. 1.

${ }^{36}$ Daniel ALIC, "Momente tensionate în existenţa Episcopiei Caransebeşului. Încercări de mutare a scaunului episcopal de la Caransebeş la Timişoara" ["Tense moments in the existence of the Diocese of Caransebes. Attempts to move the episcopal chair from Caransebes to Timisoara"], in Misiune şi propovăduire [Mission and preaching], Cluj-Napoca / Caransebes, Cluj University Press / Diocese of Caransebes Publishing House, 2013, p. 795-810.

37 ADC, Economic Fund V, File 300/1948, unnumbered. 
carrying only little luggage, not even having a car available for the trip.

Bishop Veniamin Nistor served as the abbot of the "Holy Trinity" monastery (Reunification Cathedral) in Alba Iulia, and the life he led was a continuous ordeal. From the letters to his family one can understand the hardship of his lifetime and the restrictions he went through ${ }^{38}$. He lived his life in simplicity and closely monitored by the state security. On February 5, 1963, when exactly 14 years had passed since the decree abolishing the Diocese which he had served as a bishop, aged 77, Bishop Veniamin passed away. He was buried near "Saint Lazarus" Hermitage in Alba Iulia", together with two other hierarchs of the Romanian Orthodox Church: bishops Ioan Stroia of the Army and Policarp Moruşca of the Romanians in America, the latter sharing the suffering of Bishop Veniamin.

\section{References}

1. ALIC, Daniel, Eparhia Caransebeşului în perioada păstoririi episcopului Miron Cristea (1910-1919). Biserică şi societate [The Diocese of Caransebes during the pastorate of bishop Miron Cristea (1910-1919). Church and Society], Cluj-Napoca / Caransebes, Cluj University Press / the Diocese of Caransebes Publishing House, 2013.

2. ALIC, Daniel, “Activitatea pastoral-culturală şi de asistenţă socială a episcopului Veniamin Nistor al Caransebeşului (1941-1949)" ["The pastoral-cultural and social assistance activity of Bishop Veniamin Nistor of Caransebes (1941-1949)"], in Daniel ALIC (coord.), Taină şi mărturisire [Sacrament and confession], Caransebes, Diocese of Caransebes Publishing House, 2011, p. 347-356.

3. Alic, Daniel, "Episcopul Veniamin Nistor, un mare păstor de suflete din Eparhia Caransebeşului" ["Bishop Veniamin Nistor, a great

38 Nicolae BLAJ, Vasile StANCU, Ioan LĂCĂTUŞU, “Aspecte din activitatea episcopului Veniamin Nistor şi a familiei sale păstrate în fondul arhivistic Pompiliu Nistor de la Muzeul bisericii Sfântul Nicolae din Scheii Braşovului" ["Aspects from the activity of Bishop Veniamin Nistor and his family kept in Pompiliu Nistor Archives at the Museum of Saint Nicholas of Brasov Schei Church"], in Daniel ALIC (coord.), Taină şi mărturisire [Sacrament and confession], Caransebes, Diocese of Caransebes Publishing House, 2011, p. 231-250.

39 Apud Petru Bona, Episcopia Caransebeşului [Diocese of Caransebes], $2^{\text {nd }}$ edition, Timisoara, Marineasa Publishing House, 2006, p. 221. 
shepherd of souls in the Diocese of Caransebes"], in Foaia Diecezană [Diocesan Paper], new series, vol. XXI (2015), no. 2 (February), p. 78.

4. Alic, Daniel, "Momente tensionate în existenţa Episcopiei Caransebeşului. Încercări de mutare a scaunului episcopal de la Caransebeş la Timişoara" ["Tense moments in the existence of the Diocese of Caransebes. Attempts to move the episcopal chair from Caransebes to Timisoara"], in Misiune şi propovăduire [Mission and preaching], Cluj-Napoca / Caransebes, Cluj University Press / Diocese of Caransebes Publishing House, 2013, p. 795-810.

5. Blaj, Nicolae / Stancu, Vasile / LĂCĂTuşU, Ioan, "Aspecte din activitatea episcopului Veniamin Nistor şi a familiei sale păstrate în fondul arhivistic Pompiliu Nistor de la Muzeul bisericii Sfântul Nicolae din Scheii Braşovului" ["Aspects from the activity of Bishop Veniamin Nistor and his family kept in Pompiliu Nistor Archives at the Museum of Saint Nicholas of Brasov Schei Church"], in Daniel ALIC (coord.), Taină şi mărturisire [Sacrament and confession], Caransebes, Diocese of Caransebes Publishing House, 2011, p.231250.

6. Bona, Petru, Episcopia Caransebeşului [Diocese of Caransebes], $2^{\text {nd }}$ edition, Timisoara, Marineasa Publishing House, 2006.

7. BRĂTESCU, Constantin, Episcopul Ioan Popasu şi cultura bănăţeană [Bishop Ioan Popasu and Banat culture], Timisoara, Metropolitan of Banat Publishing House, 1995.

8. CHERCIU, Viorel Dorel, "Cadrul istorico-juridic la reînființarea Diecezei Caransebeşului în anul 1865" ["Historical and legal framework at the reestablishment of the Diocese of Caransebes in 1865"], in Societate şi civilizaţie în Banatul istoric [Society and civilization in historical Banat], Timisoara, Mirton Publishing House, 2003.

9. CILIBIA, Constantin, Biserica și societatea bănățeană în timpul păstoririi episcopului dr. Iosif Traian Badescu (1920-1933) [The Church and society in Banat during the pastorate of Bishop dr. Iosif Traian Badescu (1920-1933)], Caransebes, the Diocese of Caransebes Publishing House, 2013.

10. Cornean, Nicolae, Monografia eparhiei Caransebeş [Monograph of the Diocese of Caransebes], Caransebes, 1940.

11. Cotoşman, Gheorghe, "Episcopia Caransebeşului până în pragul 
secolului al XIX-lea" ["The Diocese of Caransebes until the beginning of the nineteenth century"], in Anuarul Academiei Teologice din Caransebeş 1940-1941 [Caransebes Theological Academy Yearbook 1940-1941], Caransebes, The printing press of the diocesan publishing house, 1941.

12. GHIDIU, Andrei / BALAN, Iosif, Monografia Caransebeşului [Monograph of Caransebes], $2^{\text {nd }}$ edition, Timisoara, 2000.

13. LUPAŞ, Ioan, Episcopul Nicolae Popea [Bishop Nicolae Popea], Sibiu, Romanian Orthodox Diocese Printing House, 1933.

14. LUPAŞ, Ioan, Istoria bisericească a românilor ardeleni [Ecclesiastical History of the Romanians from Transylvania], Cluj-Napoca, Dacia Publishing House, 1995.

15. MARCU, Pavel, "Episcopul Vasile Lăzărescu” ["Bishop Vasile Lăzărescu"], in Calendarul Românului pe anul 2007 [The Romanian Calendar for 2007], Caransebes, the Diocese of Caransebes Publishing House, 2008, p.225-226.

16. MIC, Lucian, "Episcopul Ioan Popasu" ["Bishop Ioan Popasu"], in Mărturisire şi devenire în Episcopia Caransebeşului [Confession and becoming in the Diocese of Caransebes], Timişoara, Mirton Publishing House, 2010.

17. Mic, Lucian, Relaţiile Bisericii Ortodoxe Române din Banat cu Biserica Ortodoxă Sârbă în a doua jumătate a secolului al XIX-lea [The relationships of the Romanian Orthodox Church of Banat with the Serbian Orthodox Church in the second half of the nineteenth century], Cluj Napoca / Caransebes, Cluj University Press / the Diocese of Caransebes Publishing House, 2013.

18. PĂCURARIU, Mircea, Dicţionarul teologilor români [Dictionary of the Romanian Theologians], third edition revised and enlarged, Sibiu, Andreiana Publishing House, 2014.

19. PetricA, Vasile, "Episcopul Veniamin Nistor în văpaia anului 1948" ["Bishop Veniamin Nistor in the flame of 1948"], in Daniel ALIC (coord.), Taină şi mărturisire [Sacrament and confession], Caransebes, Diocese of Caransebes Publishing House, 2011, p. 356362.

20. PetricA, Vasile, Academia Teologică Ortodoxă Română Caransebeş (1927-1948) [The Romanian Orthodox Theological Academy of Caransebes (1927-1948)], Timisoara, David Press Print, 2014. 
21. POPEA, Nicolae, Vechia Mitropolie ortodoxă română a Transilvaniei, suprimarea şi restaurarea ei [The old Romanian Orthodox Metropolitan of Transylvania, its assassination and restoration], Sibiu, 1870.

22. Suciu, I. D. / Constantinescu, Radu, Documente privitoare la istoria Mitropoliei Banatului [Documents regarding the history of Banat Metropolitan], Volume II, Timisoara, Metropolitan of Banat Publishing House, 1980. 